Article

\title{
Assessment of the Suitability of 10 Winter Triticale Cultivars (x Triticosecale Wittm. ex A. Camus) for Organic Agriculture: Polish Case Study
}

\author{
Beata Feledyn-Szewczyk*iD, Małgorzata Nakielska ${ }^{\circledR}$, Krzysztof Jończyk, \\ Adam Kleofas Berbeć ${ }^{D}$ and Jerzy Kopiński \\ Department of Systems and Economics of Crop Production, Institute of Soil Science and Plant Cultivation-State \\ Research Institute, 24-100 Puławy, Poland; mnakielska@iung.pulawy.pl (M.N.); kjonczyk@iung.pulawy.pl (K.J.); \\ aberbec@iung.pulawy.pl (A.K.B.); jkop@iung.pulawy.pl (J.K.) \\ * Correspondence: bszewczyk@iung.pulawy.pl
}

Received: 9 July 2020; Accepted: 4 August 2020; Published: 6 August 2020

check for updates

\begin{abstract}
The aim of the study was to compare 10 winter triticale varieties according to their traits useful for cultivation in organic farming. The study was carried out in the years 2014-2017 in the experimental organic farm of the Institute of Soil Science and Plant Cultivation-State Research Institute in Pulawy (Poland). The highest-yielding varieties under organic conditions were Pizarro and Subito. Borowik cultivar showed the highest competitive ability against weeds. The highest number of weeds was found in the Leontyno cultivar, which was connected to the lowest plant density, the lowest weight of the above-ground parts of the canopy and smaller value of tillering coefficient. The most affected by the fungal pathogens Drechslera tritici-repentis (Died.) Shoem. and Puccinia striiformis Schwein. were Fredro and Algoso. Cluster analyses indicated that the most useful cultivars for cultivation in the organic system were: Borowik, Subito, and Tomko, which all showed higher yielding potential, bigger competitiveness against weeds, and average resistance against fungal pathogens. Pizarro, Tulus, and Twingo, which showed high resistance to fungal pathogens with lower competitiveness to weeds, were classified to the second group of usefulness. The least useful for the organic system were: Algoso, Fredro, Grenado, and Leontyno.
\end{abstract}

Keywords: winter triticale; cultivar; organic system; competitiveness; weed infestation; fungal pathogens; triticale grain yield

\section{Introduction}

Triticale (x Triticosecale Wittm. ex A. Camus) is a hybrid resulting from the crossing of a species of the genus Triticum and a species of the genus Secale [1]. Currently, the area of this cereal in the world is about 3.5 million hectares [2]. In Poland in 2018 triticale was cultivated on the area of 1 million 188 thousand ha, $93 \%$ of which was taken by winter triticale [3]. Currently there are 334 triticale varieties in the EU Common Catalogue [4]. The Polish National Register of Cultivars kept by the Research Centre for Cultivar Testing (COBORU) includes 63 cultivars of triticale in total, including 47 cultivars of winter triticale and 16 cultivars of spring triticale [5]. According to Łysoń and Biel [6], Polish triticale cultivars are among the most efficient in the world and occupy $70-80 \%$ of the world's triticale cultivation area. They also exhibit high adaptation to environmental conditions [6]. This cereal species is becoming more and more popular among farmers, also with those operating in the organic system. This is due to its beneficial traits, such as relatively low soil requirements [7,8], a higher resistance to diseases and soil acidification than wheat [6], significant yield potential [9-12], high fodder value [7,13-17], and resistance to abiotic stresses, such as drought and frost $[1,12,18]$. Winter triticale is more sensitive to a forecrop 
than rye, but less sensitive than wheat and it can be cultivated after other cereals as it responds with a relatively small reduction of yield to a less favorable forecrop [19].

Triticale is mainly used as feed grain for poultry and pigs [18,20-23]. Triticale grain from organic farming can be used for food production due to its high quality [24]. It is a valuable industrial raw material that can be used, among others, in baking and pastry making and in distillery and brewing to produce mash and malt [25], as well as to produce biofuels and animal feed [23,25]. Triticale grains exhibit a high content of protein with a favorable amino acid composition $[18,26,27]$ with a high digestibility coefficient $[26,27]$. More and more often complete animal feeds contain triticale grain instead of rye due to the presence of anti-nutritional substances such as trypsin and chymotrypsin inhibitors and resorcinols in rye [28].

Cultivation of plants in accordance with the principles of organic farming is associated with proper crop rotation $[29,30]$ and resignation from the use of synthetic mineral fertilizers and industrial plant protection products [6,29-31]. Therefore, it is very important to select an appropriate cultivar of triticale for cultivation. According to Kronberga et al. [24] and Kronberga [32] only genotypes that are resistant to snow mold, that have good winter hardiness, and that have a higher number of ears per unit of area should be selected for organic farming, as the use of such genotypes contributes to greater competitiveness against weeds as well as higher productivity. According to Kuś et al. [33], the recognition of the varietal response to pathogens is a precondition for obtaining satisfactory yields with favorable quality parameters. The desirable traits of plants grown in the organic system are high ability to compete with weeds, greater resistance to fungal diseases and good ability to absorb nutrients from the soil [34].

Weed infestation is one of the most significant problems in organic farming, because in the absence of chemical regulation the remaining methods of weed control permitted in the organic system may prove insufficient $[7,35]$. In this cultivation system weeding is initiated by preventive measures consisting of carefully performed agrotechnical treatments. In organic farming weed infestation is controlled with indirect methods (appropriate crop rotation, selection of plant species, and cultivars in the main, secondary, and subsidiary crops, sowing density, mulching, and properly performed tillage operations) as well as by direct intervention in the stand of the cultivated plant (e.g., harrowing) [36,37]. The selection of cultivars with high competitive capacity against weeds is one of the methods of indirect weed control [38] and the cultivation of cultivars with genetically conditioned resistance to pathogens is the most effective method of limiting triticale infestation in the organic system [17].

For the last 50 years as conventional agriculture has developed, cultivars of cereals have been specifically created to produce high yields under potentially unlimited use of pesticides and synthetic fertilizers. Currently, organic farmers largely depend on cultivars supplied by these conventional plant breeders [24]. In the literature there is very little research on triticale performance in organic system $[9,24]$.

Our hypothesis was that it is possible to choose among conventional triticale cultivars those that are suitable for cultivation in the organic farming system.

The aim of the study was to compare the characteristics of 10 winter triticale cultivars in terms of their suitability for organic farming and to define the cultivars with the highest and lowest suitability for this farming system. The following variables were adopted as measures of cultivar suitability for organic agriculture: morphological features, canopy parameters, competitiveness against weeds, resistance to fungal diseases, and grain yield.

\section{Materials and Methods}

\subsection{Site Characteristics, Experimental Design, and Agronomic Practices}

The study was conducted in 3 growing seasons: 2014/2015, 2015/2016 and 2016/2017 in the Experimental Station of the Institute of Soil Science and Plant Cultivation-State Research Institute in Grabów, Mazovian voivodeship, Poland, on fields managed organically since 2008. Ten winter triticale 
cultivars included in the Common Catalogue of varieties of agricultural plant species [4] that differed in their features were cultivated: Algoso, Borowik, Fredro, Grenado, Leontyno, Pizarro, Subito, Tomko, Tulus, Twingo. The cultivars were selected on the basis of criteria developed in previous studies with other cereal species and took into account: wintering stability, susceptibility to fungal diseases, morphological differentiation, and yields obtained in conventional farms [34,37,39-43]. The field experiment was established in a system of random blocks in four replications for each cultivar. The area of each plot of replication for sowing and harvest was $30 \mathrm{~m}^{2}$. Pre-sowing treatments were performed in accordance with good agricultural practice, and sowing was at the optimum time for the region (first half of September). The sowing rates were the same for each cultivar -450 grains $\cdot \mathrm{m}^{-2}$. The row spacing was $12 \mathrm{~cm}$ and the planting depth $3.5 \mathrm{~cm}$. According to organic agriculture rules, mineral fertilizers and other agrochemicals were not used [30]. Final harvests were carried out in the first decade of August. Habitat conditions prevailing in the years of the study are presented in Table 1.

Table 1. Characteristics of the soil and habitat conditions in the experiment.

\begin{tabular}{cc}
\hline Parameter & Characteristics \\
\hline Type of soil & Cambisol \\
\hline Soil texture & loamy sand \\
\hline Content of: & \\
humus $(\%)$ & 2.3 \\
$\mathrm{P}_{2} \mathrm{O}_{5}\left(\mathrm{mg} \cdot 100 \mathrm{~g}^{-1}\right.$ soil $)$ & 6.8 \\
$\mathrm{~K}_{2} \mathrm{O}\left(\mathrm{mg} \cdot 100 \mathrm{~g}^{-1}\right.$ soil $)$ & 7.1 \\
$\mathrm{Mg}\left(\mathrm{mg} \cdot 100 \mathrm{~g}^{-1}\right.$ soil $)$ & 5.8 \\
\hline $\mathrm{pH} \mathrm{w} \mathrm{KCl}$ & 5.8 \\
\hline Pre-crop & Cereal-legume mixture \\
\hline
\end{tabular}

\subsection{Meteorological Conditions}

The experimental site belongs to a moderately continental climate zone. Average annual precipitation is $655 \mathrm{~mm}$ with a mean air temperature of $7.6^{\circ} \mathrm{C}$ (data from the years 1951-2013). The meteorological data for the research period is presented in Table 2. In autumn 2014 temperatures were higher than the long-term average, while rainfall, especially in September, was one quarter of the average. In May 2015 precipitation was significantly higher than the long-term average, which resulted in increased weeds and fungal pathogens. In the period from June to August 2015 a deepening drought was observed. In October precipitation was about one quarter of the average for that month. November, on the other hand, was the warmest, and the rainfall was the highest of all the years of the research. In the 2016 growing season temperatures were above average, and May saw a shortage of precipitation. In October and November, the temperatures were slightly below the average, while the precipitation in October was higher than the average for that month. In 2017 there was a deficiency of rainfall from May to the end of June, which negatively affected the triticale yields.

Table 2. Total precipitation and average monthly temperatures in Grabów.

\begin{tabular}{ccccccccc}
\hline & \multicolumn{3}{c}{ Sum of Precipitation $\mathbf{( m m )}$} & \multicolumn{3}{c}{ Temperature $\left({ }^{\circ} \mathbf{C}\right)$} \\
\cline { 2 - 8 } Month & $\mathbf{2 0 1 4 / 2 0 1 5}$ & $\mathbf{2 0 1 5 / 2 0 1 6}$ & $\mathbf{2 0 1 6 / 2 0 1 7}$ & $\begin{array}{c}\text { Long-Term Data } \\
\mathbf{1 9 5 1 - 2 0 1 3}\end{array}$ & $\mathbf{2 0 1 4 / \mathbf { 2 0 1 5 }}$ & $\mathbf{2 0 1 5 / 2 0 1 6}$ & $\mathbf{2 0 1 6 / 2 0 1 7}$ & $\begin{array}{c}\text { Long-Term Data } \\
\mathbf{1 9 5 1 - 2 0 1 3}\end{array}$ \\
\hline IX & 15.9 & 93.9 & 20.3 & 50.0 & 17.9 & 150 & 15.7 & 13.0 \\
X & 28.5 & 12.2 & 78.5 & 42.0 & 9.8 & 6.8 & 7.4 & 8.0 \\
XI & 25.7 & 38.7 & 30.4 & 52.0 & 4.7 & 5.0 & 2.8 & 3.0 \\
XII & 36.3 & 24.0 & 66.4 & 26.0 & 0.5 & 3.9 & 0.6 & -0.8 \\
I & 40.3 & 32.1 & 33.0 & 42.0 & 1.0 & -3.6 & 4.8 & -3.7 \\
II & 15.1 & 64.1 & 37.0 & 29.0 & 0.5 & 3.4 & -1.2 & -3.0 \\
III & 63.2 & 52.3 & 36.0 & 32.0 & 5.0 & 3.9 & 5.7 & 0.8 \\
\hline
\end{tabular}


Table 2. Cont.

\begin{tabular}{|c|c|c|c|c|c|c|c|c|}
\hline \multirow[b]{2}{*}{ Month } & \multicolumn{4}{|c|}{ Sum of Precipitation (mm) } & \multicolumn{4}{|c|}{ Temperature $\left({ }^{\circ} \mathrm{C}\right)$} \\
\hline & $2014 / 2015$ & $2015 / 2016$ & $2016 / 2017$ & $\begin{array}{c}\text { Long-Term Data } \\
1951-2013\end{array}$ & $2014 / 2015$ & $2015 / 2016$ & $2016 / 2017$ & $\begin{array}{c}\text { Long-Term Data } \\
1951-2013\end{array}$ \\
\hline IV & 34.8 & 45.1 & 69.0 & 42.0 & 8.1 & 9.2 & 7.5 & 7.5 \\
\hline V & 107.0 & 39.4 & 34.0 & 53.0 & 12.7 & 14.9 & 13.9 & 12.4 \\
\hline VI & 30.3 & 60.1 & 33.0 & 110.0 & 16.9 & 18.7 & 18.1 & 16.7 \\
\hline VII & 51.7 & 81.9 & 86.0 & 105.0 & 19.7 & 19.2 & 18.6 & 17.8 \\
\hline VIII & 6.2 & 53.6 & 55.0 & 72.0 & 22.1 & 18.1 & 19.6 & 17.1 \\
\hline
\end{tabular}

\subsection{Weed Infestation Analyses}

The number of weeds and their dry matter were assessed at the dough stage of triticale (BBCH 85-87) [44], using the weight-counting method, on an area of $1 \mathrm{~m}^{2}$ in each plot of replication. To avoid the edge effect the frames were placed two meters from the edges of the plots. Weeds were cut at the soil level, sorted by hand and indicated to species according to Rutkowski [45]. The dry matter of weeds and wheat was determined after drying at $40{ }^{\circ} \mathrm{C}$ for 7 days.

\subsection{Assessment of Plant Infestation by Pathogens}

Assessments of the condition of plant infestation by pathogens were performed in 2016-2017 at the stage of milky wax maturity (BBCH 77-83) on the three uppermost leaves. For phytopathological analysis these three leaves were taken from 10 plants in each of the 4 repetitions. The percentage of leaf-blade surface damaged by individual pathogens was determined. The method of disease assessment on leaves were in accordance with European and Mediterranean Plant Protection Organization (EPPO) recommendations [46].

\subsection{Biometric Analyses and Grain Yield}

Biometric analyses of triticale height and number of tillers per plant (tillering coefficient) were performed on 30 plants, in 4 repetitions for each cultivar, at the dough stage of triticale. The plant density and dry matter of the above-ground parts were determined from $1 \mathrm{~m}^{2}$, in 4 repetitions, for each cultivar. Harvest was done using a special small harvester for the entire plot area. Grain yield was evaluated after harvest and calculated as $\mathrm{t} \cdot \mathrm{ha}^{-1}$ at $15 \%$ moisture content.

\subsection{Statistical Analyses}

Analysis of variation (ANOVA) was done, where cultivars and years were the factors of the experiment (10 cultivars $\times 3$ years). Since the number and weight of weeds did not have a normal distribution, a logarithmic transformation $\log (x+1)$ of the data was carried out before the analysis of variance. The significance of differences between treatments was verified by Tukey's test at $p \leq 0.05$. To estimate how the features of the triticale cultivars influence the parameters of weed infestation, Spearman's correlation coefficients between the number of weeds and their dry matter and the morphological features, and the canopy parameters were assessed for all tested cultivars. Cluster analysis using the furthest neighbor method was done to divide the samples into groups with similar characteristics. The following variables were used in cluster analysis: number of weeds, dry matter of weeds, infestation by pathogens, and grain yield. Calculations were performed using Statistica 10 software (Stat. Soft. Inc., Tulsa, OK, USA).

\section{Results and Discussion}

\subsection{Competitiveness against Weeds}

The level of weed infestation of the triticale cultivars depended on the morphological traits of the cultivars and the structure of the canopy. The highest competitive capacity, measured both by the number $\left(91.2\right.$ plants $\left.\cdot \mathrm{m}^{-2}\right)$ and dry weight of weeds $\left(39.4 \mathrm{~g} \cdot \mathrm{m}^{-2}\right)$, was shown by the winter triticale 
cultivar Borowik (Table 3). This was due to the large height of this cultivar (Table 4) and the large plant density and weight of the above-ground parts (Table 5). The highest weed weight was found under the canopy of the low height cultivar Grenado $\left(80.0 \mathrm{~g} \cdot \mathrm{m}^{-2}\right)$ (Tables 3 and 4$)$. On the other hand, the highest number of weeds (120.0 plants $\mathrm{m}^{-2}$ ) was recorded in the stand of the Leontyno cultivar (Table 3), which was associated with the small tillering of this cultivar (Table 4) as well as the smallest plant density and the lowest weight of the above-ground parts (Table 5).

Table 3. Number and dry matter of weeds in triticale cultivars grown in the organic system at the dough stage.

\begin{tabular}{ccccccccc}
\hline \multirow{2}{*}{ Cultivar } & \multicolumn{3}{c}{${\text { Number of Weeds (Plants· }{ }^{-2} \text { ) }}$} & \multicolumn{3}{c}{ Dry Weight of Weeds $\left(\mathbf{g} \cdot \mathbf{m}^{-\mathbf{2}}\right)$} \\
\cline { 2 - 9 } & $\mathbf{2 0 1 5}$ & $\mathbf{2 0 1 6}$ & $\mathbf{2 0 1 7}$ & Mean & $\mathbf{2 0 1 5}$ & $\mathbf{2 0 1 6}$ & $\mathbf{2 0 1 7}$ & Mean \\
\hline Algoso & $84.0 \mathrm{ab}$ & $106.0 \mathrm{a}$ & $142.5 \mathrm{a}$ & $110.8 \mathrm{a}$ & $52.5 \mathrm{abc}$ & $99.9 \mathrm{a}$ & $46.7 \mathrm{a}$ & $66.4 \mathrm{ab}$ \\
Borowik & $52.5 \mathrm{a}$ & $81.5 \mathrm{a}$ & $139.5 \mathrm{a}$ & $91.2 \mathrm{a}$ & $26.5 \mathrm{a}$ & $65.0 \mathrm{a}$ & $26.6 \mathrm{a}$ & $39.4 \mathrm{a}$ \\
Fredro & $85.0 \mathrm{ab}$ & $98.0 \mathrm{a}$ & $167.5 \mathrm{a}$ & $116.8 \mathrm{a}$ & $40.6 \mathrm{abc}$ & $87.0 \mathrm{a}$ & $52.9 \mathrm{a}$ & $60.2 \mathrm{ab}$ \\
Grenado & $85.5 \mathrm{ab}$ & $86.0 \mathrm{a}$ & $154.0 \mathrm{a}$ & $108.5 \mathrm{a}$ & $74.8 \mathrm{bc}$ & $89.4 \mathrm{a}$ & $75.8 \mathrm{a}$ & $80.0 \mathrm{~b}$ \\
Leontyno & $117.0 \mathrm{~b}$ & $82.5 \mathrm{a}$ & $160.5 \mathrm{a}$ & $120.0 \mathrm{a}$ & $84.5 \mathrm{c}$ & $68.4 \mathrm{a}$ & $40.0 \mathrm{a}$ & $64.3 \mathrm{ab}$ \\
Pizarro & $78.5 \mathrm{ab}$ & $95.0 \mathrm{a}$ & $157.5 \mathrm{a}$ & $110.3 \mathrm{a}$ & $40.4 \mathrm{abc}$ & $48.7 \mathrm{a}$ & $74.3 \mathrm{a}$ & $54.5 \mathrm{ab}$ \\
Subito & $63.0 \mathrm{ab}$ & $78.5 \mathrm{a}$ & $150.5 \mathrm{a}$ & $97.3 \mathrm{a}$ & $42.2 \mathrm{abc}$ & $57.1 \mathrm{a}$ & $53.6 \mathrm{a}$ & $51.0 \mathrm{ab}$ \\
Tomko & $88.5 \mathrm{ab}$ & $72.5 \mathrm{a}$ & $141.0 \mathrm{a}$ & $100.7 \mathrm{a}$ & $49.6 \mathrm{abc}$ & $46.4 \mathrm{a}$ & $24.8 \mathrm{a}$ & $40.3 \mathrm{ab}$ \\
Tulus & $86.5 \mathrm{ab}$ & $83.5 \mathrm{a}$ & $166.5 \mathrm{a}$ & $112.2 \mathrm{a}$ & $65.4 \mathrm{bc}$ & $55.6 \mathrm{a}$ & $62.3 \mathrm{a}$ & $61.1 \mathrm{ab}$ \\
Twingo & $59.0 \mathrm{ab}$ & $80.0 \mathrm{a}$ & $173.0 \mathrm{a}$ & $104.0 \mathrm{a}$ & $30.5 \mathrm{ab}$ & $66.1 \mathrm{a}$ & $55.8 \mathrm{a}$ & $50.8 \mathrm{ab}$ \\
Mean & $80.0 \mathrm{~A}$ & $86.4 \mathrm{~A}$ & $155.3 \mathrm{~B}$ & 107.2 & $50.7 \mathrm{~A}$ & $68.3 \mathrm{~B}$ & $51.3 \mathrm{~A}$ & 56.8 \\
\hline
\end{tabular}

${ }^{1}$ Different letters after the mean values indicate significant differences $(p \leq 0.05)$. For significant model effects a post hoc Tukey's honest significance difference (HSD) test was performed to compare mean values.

Table 4. Tillering coefficient and height of triticale cultivars grown in the organic system at the dough stage.

\begin{tabular}{ccccccccc}
\hline \multirow{2}{*}{ Cultivar } & \multicolumn{9}{c}{ Number of Tillers Per Plant } & \multicolumn{5}{c}{ Height (cm) } \\
\cline { 2 - 8 } & $\mathbf{2 0 1 5}$ & $\mathbf{2 0 1 6}$ & $\mathbf{2 0 1 7}$ & Mean & $\mathbf{2 0 1 5}$ & $\mathbf{2 0 1 6}$ & $\mathbf{2 0 1 7}$ & Mean \\
\hline Algoso & $1.8 \mathrm{a}$ & $1.4 \mathrm{a}$ & $1.1 \mathrm{a}$ & $1.4 \mathrm{a}$ & $112 \mathrm{def}$ & $109 \mathrm{c}$ & $94 \mathrm{~d}$ & $105 \mathrm{c}$ \\
Borowik & $1.5 \mathrm{a}$ & $1.4 \mathrm{a}$ & $1.2 \mathrm{a}$ & $1.4 \mathrm{a}$ & $121 \mathrm{f}$ & $108 \mathrm{bc}$ & $97 \mathrm{~d}$ & $108 \mathrm{c}$ \\
Fredro & $1.6 \mathrm{a}$ & $1.4 \mathrm{a}$ & $1.3 \mathrm{a}$ & $1.4 \mathrm{a}$ & $112 \mathrm{def}$ & $109 \mathrm{c}$ & $76 \mathrm{ab}$ & $99 \mathrm{c}$ \\
Grenado & $1.8 \mathrm{a}$ & $1.4 \mathrm{a}$ & $1.3 \mathrm{a}$ & $1.5 \mathrm{a}$ & $88 \mathrm{ab}$ & $88 \mathrm{a}$ & $76 \mathrm{ab}$ & $84 \mathrm{ab}$ \\
Leontyno & $1.6 \mathrm{a}$ & $1.3 \mathrm{a}$ & $1.1 \mathrm{a}$ & $1.3 \mathrm{a}$ & $108 \mathrm{cde}$ & $105 \mathrm{abc}$ & $92 \mathrm{~cd}$ & $102 \mathrm{c}$ \\
Pizarro & $1.6 \mathrm{a}$ & $1.3 \mathrm{a}$ & $1.3 \mathrm{a}$ & $1.4 \mathrm{a}$ & $120 \mathrm{ef}$ & $113 \mathrm{c}$ & $89 \mathrm{~cd}$ & $107 \mathrm{c}$ \\
Subito & $1.7 \mathrm{a}$ & $1.5 \mathrm{a}$ & $1.2 \mathrm{a}$ & $1.5 \mathrm{a}$ & $105 \mathrm{~cd}$ & $102 \mathrm{abc}$ & $86 \mathrm{~cd}$ & $98 \mathrm{bc}$ \\
Tomko & $1.6 \mathrm{a}$ & $1.4 \mathrm{a}$ & $1.3 \mathrm{a}$ & $1.4 \mathrm{a}$ & $97 \mathrm{bc}$ & $102 \mathrm{abc}$ & $83 \mathrm{bc}$ & $94 \mathrm{abc}$ \\
Tulus & $1.6 \mathrm{a}$ & $1.3 \mathrm{a}$ & $1.1 \mathrm{a}$ & $1.4 \mathrm{a}$ & $112 \mathrm{def}$ & $110 \mathrm{c}$ & $91 \mathrm{~cd}$ & $104 \mathrm{c}$ \\
Twingo & $1.8 \mathrm{a}$ & $1.5 \mathrm{a}$ & $1.4 \mathrm{a}$ & $1.6 \mathrm{a}$ & $86 \mathrm{a}$ & $89 \mathrm{ab}$ & $72 \mathrm{a}$ & $82 \mathrm{a}$ \\
Mean & $1.7 \mathrm{C}$ & $1.4 \mathrm{~B}$ & $1.2 \mathrm{~A}$ & 1.4 & $106 \mathrm{~B}$ & $104 \mathrm{~B}$ & $97 \mathrm{~A}$ & 102 \\
\hline
\end{tabular}

${ }^{1}$ Different letters after the mean values indicate significant differences $(p \leq 0.05)$. For significant model effects a post hoc Tukey's honest significance difference (HSD) test was performed to compare mean values.

In 2017 a significantly higher number of weeds ( 155.3 plants $\cdot \mathrm{m}^{-2}$ on average from all the cultivars) was recorded than in 2015 and 2016 (80.0 and 86.4 plants $\cdot \mathrm{m}^{-2}$, respectively) (Table 3). However, these were mainly small plants, with the domination of Viola arvensis Murr., Stellaria media (L.) Vill., Capsella bursa-pastoris (L.) Medik., Apera spica-venti (L.) P.Beauv and Papaver rhoeas L., as demonstrated by the relatively small dry weight of weeds in $2017\left(51.3 \mathrm{~g} \cdot \mathrm{m}^{-2}\right.$ on average).

Among the cultivars studied, Twingo (1.6 on average) and Grenado and Subito (1.5 on average) exhibited the largest, while Leontyno (1.3) showed the smallest overall tillering (Table 4). The tallest cultivars were Borowik (108 cm on average) and Pizarro $(107 \mathrm{~cm})$, while the shortest were Twingo $(82 \mathrm{~cm})$ and Grenado $(84 \mathrm{~cm})$. In 2017, the cultivars were significantly lower in height and less tillered than in the previous years, which was due to weather conditions (low temperatures during emergence and in 
spring, and low and uneven precipitation during the growing season) (Tables 2 and 4). The Leontyno cultivar was characterized by significantly the lowest crop plant density and weight of the above-ground parts of the canopy in 2015 and 2016 (Table 5), which had a negative effect on its competitiveness against weeds (Table 3). Pizarro was characterized by the highest plant density and the biggest weight of the above-ground parts of the canopy in 2015 (Table 5).

Table 5. Plant density and dry matter of triticale cultivars grown in an organic system at the dough stage.

\begin{tabular}{|c|c|c|c|c|c|c|c|c|}
\hline \multirow{2}{*}{ Cultivar } & \multicolumn{4}{|c|}{ Plant Density (Plants $\cdot \mathrm{m}^{-2}$ ) } & \multicolumn{4}{|c|}{ Dry Matter of Above-Ground Parts $\left(\mathrm{g} \cdot \mathrm{m}^{-2}\right)$} \\
\hline & 2015 & 2016 & 2017 & Mean & 2015 & 2016 & 2017 & Mean \\
\hline Algoso & $211 \mathrm{ab}^{1}$ & $217 \mathrm{ab}$ & $339 a$ & $256 \mathrm{ab}$ & $1110 \mathrm{ab}$ & $1351 \mathrm{a}$ & $976 a$ & 1146 a \\
\hline Borowik & $230 \mathrm{ab}$ & $233 \mathrm{ab}$ & 347 a & $270 \mathrm{ab}$ & $1377 \mathrm{ab}$ & 1346 a & 892 a & $1205 a$ \\
\hline Fredro & $238 \mathrm{ab}$ & $213 \mathrm{ab}$ & $303 a$ & $251 \mathrm{ab}$ & $1119 \mathrm{ab}$ & 1168 a & $774 \mathrm{a}$ & $1020 \mathrm{a}$ \\
\hline Grenado & $228 \mathrm{ab}$ & $257 \mathrm{ab}$ & $310 \mathrm{a}$ & $265 \mathrm{ab}$ & $1224 \mathrm{ab}$ & 1275 a & 886 a & 1128 a \\
\hline Leontyno & $179 \mathrm{a}$ & $207 a$ & $269 a$ & $218 \mathrm{a}$ & 1019 a & $1186 \mathrm{a}$ & 807 a & $1004 \mathrm{a}$ \\
\hline Pizarro & $278 \mathrm{~b}$ & $293 \mathrm{~b}$ & $347 a$ & $306 \mathrm{~b}$ & $1616 \mathrm{~b}$ & $1646 a$ & 857 a & 1373 a \\
\hline Subito & $220 \mathrm{ab}$ & $222 a b$ & 327 a & $256 \mathrm{ab}$ & $1292 a b$ & $1232 \mathrm{a}$ & 913 a & 1146 a \\
\hline Tomko & $212 a b$ & $256 \mathrm{ab}$ & $351 \mathrm{a}$ & $273 a b$ & $1311 \mathrm{ab}$ & 1454 a & 1011 a & 1259 a \\
\hline Tulus & $200 \mathrm{ab}$ & $225 \mathrm{ab}$ & $338 \mathrm{a}$ & $254 \mathrm{ab}$ & $1158 \mathrm{ab}$ & 1432 a & $952 \mathrm{a}$ & 1181 a \\
\hline Twingo & $242 a b$ & $247 \mathrm{ab}$ & $281 \mathrm{a}$ & $257 \mathrm{ab}$ & $1312 \mathrm{ab}$ & $1340 \mathrm{a}$ & $776 \mathrm{a}$ & $1143 \mathrm{a}$ \\
\hline Mean & $224 \mathrm{~A}$ & $237 \mathrm{~A}$ & $321 \mathrm{~B}$ & 261 & 1253 B & 1343 B & $884 \mathrm{~A}$ & 1160 \\
\hline
\end{tabular}

Correlation analysis showed that the number of weeds was significantly negatively correlated with the number of tillers per plant and plant height, as well as with triticale plant density and dry weight of the above-ground parts of triticale plants (Table 6). On the other hand, weed weight was only slightly affected by the triticale plant density.

Table 6. Spearman's correlation coefficients for weed infestation indices and morphological and structure parameters of the canopy of winter triticale (total for all cultivars and years of study, $n=120$ observations).

\begin{tabular}{cccccc}
\hline & $\begin{array}{c}\text { Dry Matter } \\
\text { of Weeds }\end{array}$ & Tillering & Height & $\begin{array}{c}\text { Triticale Plant } \\
\text { Density }\end{array}$ & $\begin{array}{c}\text { Dry Matter of } \\
\text { Above-Ground Parts }\end{array}$ \\
\hline Number of weeds & 0.126 & $-0.420 *$ & $-0.478^{*}$ & $-0.409 *$ & $-0.358^{*}$ \\
Dry matter of weeds & & 0.075 & -0.003 & $-0.180 *$ & 0.124 \\
\hline \multicolumn{7}{c}{ significant at $p \leq 0.05}$.
\end{tabular}

In the study of Mahayan et al. [47], conducted on different barley genotypes, yield losses caused by weeds ranged from $43 \%$ to $78 \%$. The level of weed infestation of cereals is influenced by the mechanical measures, fertilization, crop rotation, the species of the crop, and the selection of cultivars [48]. Triticale is less competitive against weeds than rye [49]. This is related to the slow growth rate of this plant at the initial developmental stages until the moment of canopy closure.

Studies by other authors confirm that the competitive ability of cereals against weeds depends primarily on the morphological traits of each cultivar such as: number of tillers per plant, stem length, leaf angle, leaf surface, relative growth rate [34,39,42], early canopy closure and plant height $[40,50,51]$. According to Wolfe et al. [51], even slight differences in the shading capacity of cultivars of cultivated plants affect the degree of light available to weeds and that can significantly influence their growth. On the other hand, the study by Kronberga et al. [24], conducted under Latvian conditions, showed that triticale height did not significantly influence competitiveness against weeds or yields.

The date of sowing, seed quality, plant density, field levelling and field architecture are also of great importance for the competitiveness of cereal crops against weeds [37,39]. Due to the scarcity of research on triticale some features were related to other cereals $[41,43,49]$. In the study carried out by 
Starczewski and Żoładek [49], at the highest crop density, 600 plants. $\mathrm{m}^{-2}$, the air-dry weight of weeds decreased by almost $38 \%$ and the yield of winter triticale grain increased by $15.3 \%$ in comparison to a crop density of 400 plants. $\mathrm{m}^{-2}$. The research conducted by Feledyn-Szewczyk and Jończyk [43] on oat cultivars grown in the organic system showed a negative correlation between weed infestation and the weight of the above-ground parts of oats and its tillering and height. Similarly, research carried out on winter wheat in the organic system showed that low weed infestation of wheat cultivars that showed the highest competitiveness against weeds was related to their morphological traits, such as: leaf area, stand structure, plant density, penetration of photosynthetic active radiation under the canopy and the weight of the above-ground parts of wheat [39].

\subsection{Infestation by Fungal Pathogens}

The leaf infestation of winter triticale cultivated in the organic system varied from $12.5 \%$ for the Twingo cultivar to 31.6\% for the Algoso cultivar (average from 2016-2017) (Table 7). In 2016, the biggest infestation was caused by the fungus Drechslera tritici-repentis (Died.) Shoem. and was especially found in the cultivars: Subito, Fredro, and Algoso. The smallest infestations were recorded for the cultivars: Grenado, Twingo, and Tulus. In 2017, the triticale was most infested by Puccinia striiformis Schwein. (average $9.2 \%$ of leaf blade infected) and Puccinia recondita Dietel \& Holw. (7.8\%). Development of these pathogens were favored by rainy autumn 2016 (October), warm winter 2016/2017 and wet spring 2017 (April) (Table 2). The cultivars most susceptible to fungal infections were Algoso and Borowik, while the least susceptible were Twingo, similarly as in 2016, and Pizarro. Paluch et al. [10] examined the occurrence of brown rust on the leaves of winter triticale and recorded a $24.1 \%$ higher occurrence of brown rust (Puccinia recondita) under triticale monoculture as compared with its cultivation under a three-field crop rotation system.

Diseases of cereals caused by fungal pathogens may significantly reduce grain yields and deteriorate their quality parameters [17]. The degree of cereal infestation by pathogens depends on weather conditions during the growing season [52], sensitivity of varieties to pathogens, crop rotation, nitrogen fertilization level [51,52], and the method of weed control [53]. According to Gradzielewska et al. [1], the following are threats to triticale crops: powdery mildew, various species of rust, Rhinchosporium secalis, stem base diseases, leaf and ear spotting, as well as snow mold and ergot. Triticale infestation by pathogens can lead to a 5-20\% yield reduction, and in extreme cases even to $60 \%$ [52]. According to Bielski [11], the frequency of diseases of the stem base, leaves and ears in triticale is increasing and the losses caused by these diseases may reach one third of the yield. Czajkowski and Czembor [54] state that from an economic and ecological point of view, breeding resistant varieties and seeking new effective sources of resistance among wheat and triticale genotypes are the only right way to protect cereals from the powdery mildew of cereals and grasses. According to Kramek and Kociuba [55], triticale shows an intermediate response to leaf and ear diseases compared to the parent species (wheat and rye), with the exception of resistance to mildew, which is significantly higher than it is in wheat and rye. According to Korbas and Mrówczyński [56], the date of sowing is an important factor that can significantly control plant infestation by pathogens. According to Kuś et al. [33], the complex influence of such factors as tillage, crop rotation, selection of varieties, sowing of mixtures, and fertilization with organic and natural fertilizers reduces disease pressure and influences the formation of a specific balance between pathogenic factors and saprophytic microflora and pathogen antagonists. 
Table 7. Infestation of triticale cultivars by fungal pathogens (\% of leaf blade infected, 3 upper leaves L1-L3 in total).

\begin{tabular}{|c|c|c|c|c|c|c|c|c|c|c|c|}
\hline \multirow[b]{2}{*}{ Cultivar } & \multicolumn{5}{|c|}{2016} & \multicolumn{5}{|c|}{2017} & \multirow{2}{*}{$\begin{array}{l}\text { Mean Infestation } \\
\text { of Cultivarss } \\
\text { (2016-2017) }\end{array}$} \\
\hline & $\begin{array}{c}\text { Drechslera } \\
\text { tritici-repentis }\end{array}$ & $\begin{array}{l}\text { Puccinia } \\
\text { recondita }\end{array}$ & $\begin{array}{l}\text { Puccinia } \\
\text { striiformis }\end{array}$ & $\begin{array}{l}\text { Septoria } \\
\text { sp. }\end{array}$ & SUM & $\begin{array}{c}\text { Drechslera } \\
\text { tritici-repentis }\end{array}$ & $\begin{array}{l}\text { Puccinia } \\
\text { recondita }\end{array}$ & $\begin{array}{l}\text { Puccinia } \\
\text { strifformis }\end{array}$ & $\begin{array}{l}\text { Septoria } \\
\text { sp. }\end{array}$ & SUM & \\
\hline Algoso & $6.7 \mathrm{ab}^{1}$ & $4.7 \mathrm{c}$ & $11.9 \mathrm{c}$ & $3.8 \mathrm{ab}$ & 27.1 & $2.8 \mathrm{a}$ & $14.0 \mathrm{~b}$ & $18.5 \mathrm{c}$ & $0.7 \mathrm{a}$ & 36.0 & 31.6 \\
\hline Borowik & $10.0 \mathrm{~b}$ & $0.5 \mathrm{a}$ & $5.8 \mathrm{bc}$ & $4.0 \mathrm{ab}$ & 20.3 & $2.4 \mathrm{a}$ & $3.4 \mathrm{a}$ & $19.5 \mathrm{c}$ & $2.4 \mathrm{ab}$ & 27.7 & 24.0 \\
\hline Fredro & $3.3 \mathrm{~b}$ & $2.0 \mathrm{ab}$ & $10.0 \mathrm{c}$ & $14.1 \mathrm{c}$ & 29.4 & $2.4 \mathrm{a}$ & $9.5 \mathrm{ab}$ & $7.4 \mathrm{ab}$ & $2.9 \mathrm{ab}$ & 22.2 & 25.8 \\
\hline Grenado & $4.3 \mathrm{ab}$ & $0.3 \mathrm{a}$ & $2.6 \mathrm{ab}$ & $3.0 \mathrm{ab}$ & 10.2 & $1.9 \mathrm{a}$ & $11.4 \mathrm{~b}$ & $4.6 \mathrm{a}$ & $1.8 \mathrm{ab}$ & 19.7 & 15.0 \\
\hline Leontyno & $2.5 \mathrm{a}$ & $2.4 \mathrm{~b}$ & $7.4 \mathrm{bc}$ & $2.8 \mathrm{ab}$ & 15.1 & $2.2 \mathrm{a}$ & $7.7 \mathrm{ab}$ & $11.3 \mathrm{~b}$ & $2.2 \mathrm{ab}$ & 23.4 & 19.3 \\
\hline Pizarro & $3.9 \mathrm{ab}$ & $3.0 \mathrm{bc}$ & $1.3 \mathrm{ab}$ & $7.1 \mathrm{~b}$ & 15.3 & $0.8 \mathrm{a}$ & $10.0 \mathrm{ab}$ & $2.4 \mathrm{a}$ & $1.0 \mathrm{ab}$ & 14.2 & 14.8 \\
\hline Subito & $22.0 \mathrm{c}$ & $0.5 \mathrm{~b}$ & $1.4 \mathrm{ab}$ & $6.5 \mathrm{ab}$ & 30.4 & $3.2 \mathrm{a}$ & $2.7 \mathrm{a}$ & $10.3 \mathrm{~b}$ & $1.2 \mathrm{ab}$ & 19.2 & 24.8 \\
\hline Tomko & $4.9 \mathrm{ab}$ & $3.9 \mathrm{bc}$ & $4.9 \mathrm{~b}$ & $3.2 \mathrm{ab}$ & 16.9 & $3.2 \mathrm{a}$ & $3.7 \mathrm{ab}$ & $12.1 \mathrm{a}$ & $2.0 \mathrm{ab}$ & 21.0 & 19.0 \\
\hline Tulus & $4.8 \mathrm{ab}$ & $2.8 \mathrm{bc}$ & $1.5 \mathrm{ab}$ & $3.8 \mathrm{ab}$ & 12.9 & $0.9 \mathrm{a}$ & $10.0 \mathrm{ab}$ & $3.4 \mathrm{a}$ & $5.1 \mathrm{~b}$ & 19.4 & 16.2 \\
\hline Twingo & $9.4 \mathrm{~b}$ & $0.7 \mathrm{ab}$ & $0.3 \mathrm{a}$ & $0.7 \mathrm{ab}$ & 11.1 & $2.2 \mathrm{a}$ & $6.0 \mathrm{ab}$ & $3.0 \mathrm{a}$ & $2.7 \mathrm{ab}$ & 13.9 & 12.5 \\
\hline Mean & 7.2 & 2.1 & 4.7 & 4.9 & 18.9 & 2.2 & 7.8 & 9.2 & 2.2 & 21.7 & 20.3 \\
\hline
\end{tabular}

${ }^{1}$ Different letters after the mean values indicate significant differences ( $\left.p \leq 0.05\right)$. For significant model effects a post hoc Tukey's honest significance difference (HSD) test was performed to compare mean values. 


\subsection{Yield}

In the years 2015-2017 the mean yield of winter triticale grain, regardless of cultivar, ranged from 3.56 to $6.10 \mathrm{t} \cdot \mathrm{ha}^{-1}$ (Table 8). The highest yield was recorded for triticale varieties in 2015 while the lowest yield was obtained in 2017 when unfavorable weather conditions occurred, and at the same time a higher intensity of fungal diseases, mainly brown and yellow rust, and weed infestation was recorded. The highest mean yields were noted for Pizarro (5.52 th ha ${ }^{-1}$ ) and Subito (5.49 t.ha $\left.{ }^{-1}\right)$. The characteristic trait of the Subito and Tomko varieties was the ability to produce a grain of high weight, while the Pizarro cultivar was more resistant to fungal pathogens.

Table 8. Yields and 1000 grain weight (TGW) of triticale cultivars in the organic system.

\begin{tabular}{ccccccccc}
\hline \multirow{2}{*}{ Cultivar } & \multicolumn{3}{c}{ Grain Yield (t.ha ${ }^{-1}$ ) } & \multicolumn{3}{c}{ 1000 Grain Weight (g) } \\
\cline { 2 - 8 } & $\mathbf{2 0 1 5}$ & $\mathbf{2 0 1 6}$ & $\mathbf{2 0 1 7}$ & Mean & $\mathbf{2 0 1 5}$ & $\mathbf{2 0 1 6}$ & $\mathbf{2 0 1 7}$ & Mean \\
\hline Algoso & $5.30 \mathrm{ab}^{1}$ & $5.62 \mathrm{~b}$ & $3.65 \mathrm{a}$ & $4.86 \mathrm{ab}$ & $43.3 \mathrm{~b}$ & $49.3 \mathrm{~b}$ & $42.7 \mathrm{a}$ & $45.1 \mathrm{~b}$ \\
Borowik & $6.27 \mathrm{bcd}$ & $6.13 \mathrm{c}$ & $3.54 \mathrm{a}$ & $5.31 \mathrm{bc}$ & $48.6 \mathrm{c}$ & $51.7 \mathrm{~b}$ & $50.3 \mathrm{~b}$ & $50.2 \mathrm{c}$ \\
Fredro & $6.61 \mathrm{~d}$ & $5.25 \mathrm{a}$ & $3.40 \mathrm{a}$ & $5.09 \mathrm{~b}$ & $44.1 \mathrm{bc}$ & $46.2 \mathrm{a}$ & $42.2 \mathrm{a}$ & $44.2 \mathrm{~b}$ \\
Grenado & $5.59 \mathrm{abc}$ & $5.00 \mathrm{a}$ & $3.73 \mathrm{a}$ & $4.77 \mathrm{ab}$ & $32.5 \mathrm{a}$ & $44.1 \mathrm{a}$ & $40.5 \mathrm{a}$ & $39.0 \mathrm{a}$ \\
Leontyno & $5.19 \mathrm{a}$ & $5.05 \mathrm{a}$ & $3.28 \mathrm{a}$ & $4.51 \mathrm{a}$ & $43.2 \mathrm{~b}$ & $48.4 \mathrm{ab}$ & $46.7 \mathrm{~b}$ & $46.1 \mathrm{~b}$ \\
Pizarro & $6.69 \mathrm{~d}$ & $6.26 \mathrm{c}$ & $3.60 \mathrm{ab}$ & $5.52 \mathrm{c}$ & $42.7 \mathrm{~b}$ & $45.6 \mathrm{a}$ & $39.7 \mathrm{a}$ & $42.7 \mathrm{ab}$ \\
Subito & $6.32 \mathrm{~cd}$ & $6.21 \mathrm{C}$ & $3.95 \mathrm{~b}$ & $5.49 \mathrm{c}$ & $41.4 \mathrm{~b}$ & $45.7 \mathrm{ab}$ & $46.9 \mathrm{~b}$ & $44.7 \mathrm{~b}$ \\
Tomko & $6.39 \mathrm{~cd}$ & $5.76 \mathrm{~b}$ & $3.70 \mathrm{ab}$ & $5.28 \mathrm{bc}$ & $44.2 \mathrm{bc}$ & $49.7 \mathrm{~b}$ & $48.4 \mathrm{~b}$ & $47.4 \mathrm{bc}$ \\
Tulus & $6.07 \mathrm{abcd}$ & $5.78 \mathrm{~b}$ & $3.61 \mathrm{ab}$ & $5.15 \mathrm{~b}$ & $43.5 \mathrm{~b}$ & $46.2 \mathrm{a}$ & $45.3 \mathrm{~b}$ & $45.0 \mathrm{~b}$ \\
Twingo & $6.55 \mathrm{~cd}$ & $5.41 \mathrm{ab}$ & $3.11 \mathrm{a}$ & $5.02 \mathrm{~b}$ & $42.5 \mathrm{~b}$ & $44.1 \mathrm{a}$ & $46.6 \mathrm{~b}$ & $44.4 \mathrm{~b}$ \\
Mean & $6.10 \mathrm{~A}$ & $5.65 \mathrm{~A}$ & $3.56 \mathrm{~B}$ & 5.10 & $42.6 \mathrm{~A}$ & $47.1 \mathrm{~A}$ & $44.9 \mathrm{~A}$ & 44.9 \\
\hline
\end{tabular}

${ }^{1}$ Different letters after the mean values indicate significant differences $(p \leq 0.05)$. For significant model effects a post hoc Tukey's honest significance difference (HSD) test was performed to compare mean values.

The lowest yields under the conditions of organic production were obtained by the Leontino cultivar, which was characterized by small plant density (Table 5) and low tillering coefficient (Table 4). The low plant density of the Leontino cultivar contributed to weed infestation, which was one of the highest among the evaluated cultivarss (Table 3). The Grenado cultivar was characterized by the lowest 1000 kernel weight (TKW) (39.0 g on average), which translated into the low yield of this cultivar (Table 8). The highest 1000 kernel weight was recorded for the Borowik cultivar (50.2 g on average).

Observations from other studies indicate that cereal yields in the organic system are on average 25 to $50 \%$ lower than in the conventional system, depending on the species, year, type of soil, and intensity of use of chemical means of production in the conventional system $[8,41,43]$ (Table 9).

Table 9. Comparison of triticale grain yields in organic and conventional farming systems based on own research and literature.

\begin{tabular}{|c|c|c|c|c|c|}
\hline Country & Study & Years & Cultivar/Genotype & Organic System & Conventional System \\
\hline \multicolumn{6}{|c|}{ Grain Yield $\left(t \cdot h a^{-1}\right)$} \\
\hline Poland & presented study & 2014-2017 & $\begin{array}{l}\text { average for } 10 \text { cultivars; } \\
\text { range (min-max) }\end{array}$ & $\begin{array}{c}5.10 ; \\
4.51 \text { (Leontyno)-5.52 } \\
\text { (Pizarro) }\end{array}$ & \\
\hline \multirow{2}{*}{ Latvia } & \multirow{2}{*}{ Kronberga [9] } & \multirow{2}{*}{ 2005-2007 } & $9402-32$ & $3.11-5.89$ & $4.56-6.11$ \\
\hline & & & 9540-1 & $2.73-5.62$ & $4.74-5.48$ \\
\hline \multirow{2}{*}{ Poland } & presented study & $2014-2017$ & \multirow{2}{*}{ Borowik } & 5.31 & \\
\hline & Tratwal et al. [8] & 2013-2016 & & & $10.6^{*}-11.8^{* *}$ \\
\hline \multirow{2}{*}{ Poland } & presented study & $2014-2017$ & \multirow{2}{*}{ Twingo } & 5.02 & \\
\hline & Tratwal et al. [8] & $2013-2016$ & & & $7.55 *-8.39 * *$ \\
\hline
\end{tabular}


Table 9. Cont.

\begin{tabular}{|c|c|c|c|c|c|}
\hline Country & Study & Years & Cultivar/Genotype & Organic System & Conventional System \\
\hline \multicolumn{6}{|c|}{ Grain Yield $\left(t \cdot h a^{-1}\right)$} \\
\hline \multirow{2}{*}{ Poland } & presented study & \multirow{2}{*}{2015} & \multirow{2}{*}{ Tulus } & 6.07 & \\
\hline & Tratwal et al. [8] & & & & $15.81 * *$ \\
\hline \multirow{2}{*}{ Poland } & presented study & \multirow{2}{*}{2016} & \multirow{2}{*}{ Tulus } & 5.78 & \\
\hline & Tratwal et al. [8] & & & & $5.76 *-6.59 * *$ \\
\hline Poland & Paluch et al. [10] & 2008-2010 & Grenado & & $\begin{array}{l}3.42 \text { in monoculture; } \\
4.53 \text { in crop rotation }\end{array}$ \\
\hline \multicolumn{6}{|c|}{ Thousand Kernel Weight (TKW) (g) } \\
\hline Poland & presented study & 2014-2017 & $\begin{array}{l}\text { average for } 10 \text { cultivars; } \\
\text { range (min-max) }\end{array}$ & $\begin{array}{c}44.9 ; \\
39.0 \text { (Grenado)-50.2 } \\
\text { (Borowik) }\end{array}$ & \\
\hline \multirow{2}{*}{ Latvia } & \multirow{2}{*}{ Kronberga [9] } & \multirow{2}{*}{$2005-2007$} & $9402-32$ & $43.7-51.0$ & $48.0-52.3$ \\
\hline & & & $9540-1$ & $34.4-42.7$ & $35.6-39.3$ \\
\hline \multirow{4}{*}{ Poland } & presented study & 2014-2017 & \multirow{2}{*}{ Grenado } & 39.0 & \\
\hline & Bujak et al. [57] & 2008-2010 & & & $37.94 *-36.65 * *$ \\
\hline & presented study & 2014-2017 & \multirow{2}{*}{ Borowik } & 50.2 & \\
\hline & Tratwal et al. [8] & 2013-2016 & & & $49.42 * *$ \\
\hline
\end{tabular}

* medium level of agrochemicals in conventional system; ${ }^{* *}$ high-input level of agrochemicals in conventional system.

In the studies of Tratwal et al. [8], conducted in the years 2013-2016 in the conventional system, in very good soil conditions and high level of crop management, the Borowik cultivar achieved the highest yields among the tested cultivars (10.6-11.8 tha ${ }^{-1}$ depending on the input of agrochemicals) (Table 9). In our research, under the conditions of the organic system, this cultivar also had a high yield (5.31 th $\mathrm{ha}^{-1}$ average from 3 years of research) and was the second best-yielding cultivar after Pizarro, it also had the highest 1000 kernel weight among the tested cultivars (Tables 8 and 9). In the mentioned above study by Tratwal et al. [8] the lowest yielding cultivar was Twingo, while in the current research under the conditions of organic farming it yielded at an average level. The significant differences between our results and those of Tratwal et al. [8] are due to the possibilities offered by conventional production that are not available in organic farming (mineral nitrogen fertilization, fungicide protection, foliar feeding of micro-nutrients, and use of growth regulators). In the second year (2014/2015) of the study by Tratwal et al. [8] very high yields of triticale were obtained and those were significantly different from the other 2 years of the research, and this greatly increased the average yield for the 3 years. For comparison, in 2015 in own experiment the Tulus cultivar yielded in the organic system $6.07 \mathrm{t} \cdot \mathrm{ha}^{-1}$, while in the conventional experiment of Tratwal et al. [8] the yield was more than twice bigger (Table 9). In 2016 the yield differences between the experiments in the organic and conventional systems were much smaller (5.78 th $\mathrm{ha}^{-1}$ in our study and 5.76-6.59 tha ${ }^{-1}$ in Tratwal et al. [8] research). This indicates a higher yield stability over years in the organic system compared to the conventional one. Other studies confirm that the yields of cereals in the organic system are mostly lower than in the conventional system, but more stable over the years [41]. Our results and Jaśkiewicz et al. [58] and Jaśkiewicz and Jasińska [59] study suggest that it is possible in organic agriculture to obtain a yield of cereals that is similar or even higher than that obtained from the conventional system (Table 9).

In our research the 1000 kernel weight (TKW) of the tested triticale was on average from $39.0 \mathrm{~g}$ (Grenado) to $50.2 \mathrm{~g}$ (Borowik), similarly to Kronberga [9] results (Table 9). In the studies of Tratwal et al. [8], under conditions of high-input conventional agriculture, the variety with the highest TKW was also Borowik $(49.42 \mathrm{~g})$. This indicates that this cultivar responds similarly under conventional and organic farming conditions, and can therefore be recommended for organic agriculture. 


\subsection{Suitability for Organic Farming}

Cluster analysis showed that the cultivars most useful for organic farming, exhibiting the highest grain yields and the least weed infestation, were Borowik, Subito and Tomko (Table 10, Figure 1). Pizarro, Tulus, and Twingo were also distinguished by favorable parameters in terms of fungal disease and weed infestation, as well as giving high yields. Algoso, Fredro, Grenado, and Leontyno were the least useful for the organic farming system. They produced low yields and they were suffering from the highest number and weight of weeds and a high leaf infestation by fungal pathogens.

Table 10. Cluster analysis for triticale cultivars taking into account yields and the most important yield-limiting factors (average from 2015-2017).

\begin{tabular}{cccccc}
\hline Cluster & Cultivars & $\begin{array}{c}\text { Number of Weeds } \\
\text { Per } \mathbf{1} \mathbf{~ m}^{\mathbf{2}}\end{array}$ & $\begin{array}{c}\text { Dry Matter of } \\
\text { Weeds } \mathbf{( g \cdot \mathbf { m } ^ { - 2 } )}\end{array}$ & $\begin{array}{c}\text { Infestation by } \\
\text { Pathogens } \\
(\mathbf{\%} \text { Leaf Area) }\end{array}$ & $\begin{array}{c}\text { Yield } \\
\left(\mathbf{t} \cdot \mathbf{h a}^{\mathbf{- 1}} \mathbf{)}\right.\end{array}$ \\
\hline 1 & $\begin{array}{c}\text { Algoso, Fredro, } \\
\text { Grenado, Leontyno }\end{array}$ & 114.0 & 67.7 & 22.9 & 4.81 \\
\hline 2 & Borowik, Subito, Tomko & 96.4 & 43.5 & 22.6 & 5.36 \\
\hline 3 & Pizarro, Tulus, Twingo & 108.8 & 55.5 & 14.5 & 5.23 \\
\hline
\end{tabular}

\section{Dendrogram \\ Furthest Neighbor Method,Squared Euclidean}

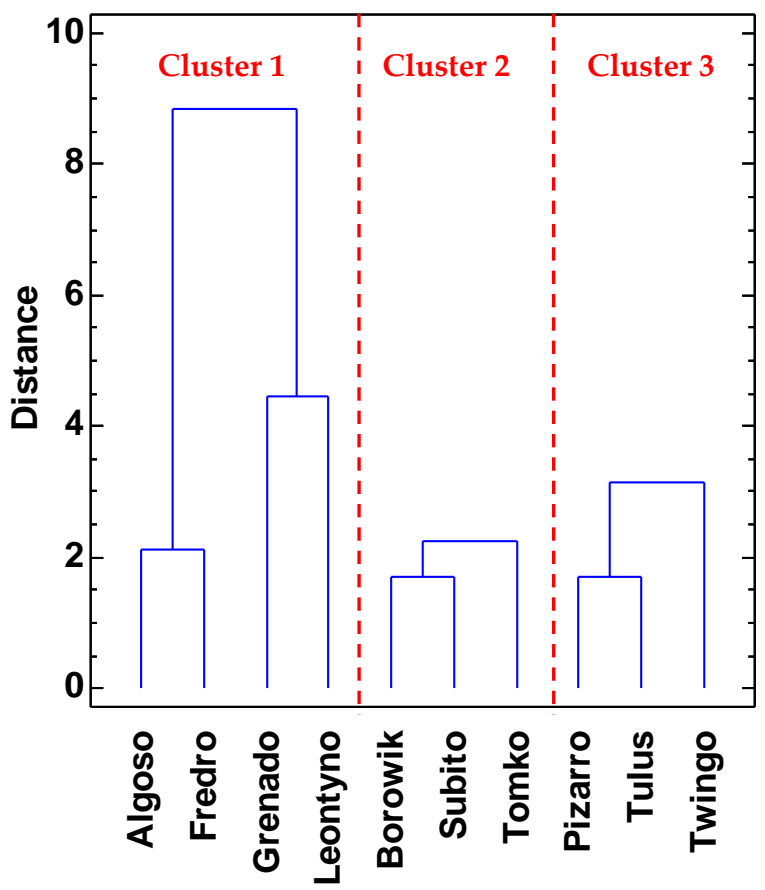

Figure 1. Dendrogram for cluster analysis of winter triticale cultivars grown in the organic system.

Triticale is suitable for growing in organic farming due to its stable yield, tolerance to marginal conditions, resistance to diseases, and high competitive ability against weeds [24,32]. According to WendaPiesik and Wasilewski [60], triticale performs much better in less favorable habitat conditions, such as dry soils with nutrient deficiencies, unfavorable temperature distribution, or organic farming conditions, compared to wheat. Triticale yields are influenced by cultivar, local climate, agro-ecological conditions, mineral fertilization, protection against diseases, weeds and pests [61]. In turn, Le Campion et al. [31] state that the availability of nitrogen at the period of stem formation is the main factor limiting the yield of winter cereals grown in the organic system. 
When selecting cultivars that perform best in organic conditions a given cultivar should be assessed in terms of its characteristics important from the point of view of farmers and organic processors [50]. In our research it was found that both higher resistance to pathogens and competitiveness against weeds were important features of a cultivar and that they influenced its grain yield. Furthermore, the level of weed infestation was correlated with the tillering and height of plants, the density of triticale plants and the dry mass of the above-ground parts of the canopy. Kronberga's study [32], conducted in Latvian conditions, confirmed that important traits for organic crop ideotype of triticale are: good winter hardiness, resistance to snow mold, good weed competitiveness, early maturity, prostrate growth habit, and greater leaf size. According to Koziara et al. [62], primarily genetic conditions, and to a lesser extent habitat conditions and the applied agrotechnology determine the achievement of satisfactory yields and that is why it is so important to look for and select suitable cultivars for organic farming.

\section{Conclusions}

It can be concluded that under the conditions of the organic system the Borowik cultivar of triticale showed the highest competitive ability against weeds, while the Leontyno cultivar showed the smallest. The number of weeds was significantly negatively correlated with the tillering and height of plants, as well as with the density of triticale plants and the dry matter of the above-ground parts of the canopy. The pathogens most infesting the triticale cultivated in the organic system were Drechslera tritici-repentis (Died.) Shoem. and Puccinia striiformis Schwein. The least infested cultivars were Twingo and Pizarro. The highest-yielding cultivars in the organic system were Pizarro and Subito. The Borowik cultivar had the highest 1000 grain weight. Two groups of triticale cultivars with features that identify them as suitable for cultivation under conditions of organic production were distinguished. The first group consisted of the cultivars: Borowik, Subito, Tomko, and they have the highest yielding potential, higher competitiveness against weeds, and average resistance to fungal pathogens occurring on leaves. The second group consisted of the cultivars: Pizarro, Tulus, Twingo, which showed higher resistance to fungal pathogens than the first group, but lower competitiveness against weeds. The least useful cultivars for the organic system turned out to be: Algoso, Fredro, Grenado, and Leontyno. Our results showed also that it is possible in organic agriculture to obtain a yield of cereals that is similar or even higher than that obtained from the conventional system.

Author Contributions: Conceptualization, K.J.,; methodology, B.F.-S., K.J.; validation, A.K.B., J.K.; investigation, B.F.-S., K.J., A.K.B.; data curation, B.F.-S., M.N., K.J.; writing-original draft preparation, M.N., B.F.-S.; writing-review and editing, K.J., J.K., A.K.B.; visualization, B.F.-S., M.N.; supervision, B.F.S., K.J.; project administration, K.J.; funding acquisition, K.J., J.K. All authors have read and agreed to the published version of the manuscript.

Funding: The study was carried out under the project co-financed by Polish Ministry of Rural Development No HORre-027.4.2017. The publication was prepared under and the multi-annual program of IUNG-PIB, Task No 2.1. (2016-2020).

Conflicts of Interest: The authors declare no conflict of interest. The funders had no role in the design of the study; in the collection, analyses, or interpretation of data; in the writing of the manuscript, or in the decision to publish the results.

\section{References}

1. Grądzielewska, A.; Gruszecka, D.; Paczos-Grzęda, E. Evaluation of hybrids between triticale and Aegilops crassa $4 \times$ Boiss applying RAPD and ISSR methods. Folia Pomer. Univ. Technol. Stetin. Agric. Aliment. Pisc. Zootech. 2010, 276, 19-30. (In Polish)

2. Food and Agriculture Organization of the United Nations. Crops. Available online: http://www.fao.org/ faostat/en/\#data/QC (accessed on 20 May 2020).

3. Łączyński, A. Land Use and Sown Area in 2018; Central Statistical Office: Poland, Warsaw, 2019; p. 74. Available online: http://www.stat.gov.pl (accessed on 20 May 2020). 
4. EU Common Catalogue of Varieties of Agricultural Plant Species. 2019. Consolidated Version, 20 September2019. Available online: https://ec.europa.eu/food/sites/food/files/plant/docs/plant_variety_catalogues_agriculturalplant-species.pdf (accessed on 20 May 2020).

5. Research Centre for Cultivar Testing (COBORU), 2020. Available online: www.coboru.pl/Polska/Rejestr/ odm_w_rej.aspx?kodgatunku=PZZO (accessed on 20 May 2020).

6. Łysoń, E.; Biel, W. The effect of the cultivation system of selected winter triticale grain $(\times$ Triticosecale Wittm. ex A. Camus) cultivars on the nutritional value. Ann. UMCS Sec. E Agric. 2016, LXXI, 53-63. (In Polish)

7. Parylak, D.; Pytlarz, E.; Paluch, M. Changes of weed infestation in the long-term continuous cropping of winter triticale. Fragm. Agron. 2016, 33, 63-70. (In Polish)

8. Tratwal, A.; Roik, K.; Kardasz, P.; Bocianowski, J. Yielding varieties of winter triticale in Post Registration Trials. Zagadnienia Doradztwa Rolniczego 2018, 4, 73-88. (In Polish)

9. Kronberga, A. Selection criteria in triticale breeding for organic farming. Agron. Vestis (Latvian J. Agron.) 2008, 11, 89-94.

10. Paluch, M.; Parylak, D.; Ogórek, R.; Tendziagolska, E. The possibility of the limitation of brown rust (Puccinia recondita) occurrence infection on winter triticale grown as continuous crop by application of soil conditioners and effective microorganisms. Zesz. Nauk. UP Wroc. Agric. CII 2012, 588, 137-144. (In Polish)

11. Bielski, S. Effect of nitrogen fertilization and fungicide protection on winter triticale wholesomeness. Acta Sci. Pol. Agric. 2015, 14, 3-14.

12. Cantale, C.; Petrazzuolo, F.; Correnti, A.; Farneti, A.; Felici, F.; Latini, A.; Galeffi, P. Triticale for bioenergy production. Agric. Agric. Sci. Procedia 2016, 8, 609-616. [CrossRef]

13. Iwański, R.; Wianecki, M.; Tokarczyk, G.; Stankowski, S. The influence of conventional and ecological tillage system method of triticale on bakery value of flour and quality of bread. Folia Pomer. Univ. Technol. Stetin. Agric. Aliment. Pisc. Zootech. 2009, 269, 19-32. (In Polish)

14. Paluch, M.; Parylak, D.; Giemza-Mikoda, M.; Jabłońska, M. The influence of proecological practices in winter triticale growing in the continuous crop on physical soils properties. Episteme 2012, 15, 197-202.

15. Jaśkiewicz, B.; Szczepanek, M. Amino acids content in triticale grain depending on meteorological, agrotechnical and genetic factors. Res. Rural Dev. 2018, 2, 28-34. [CrossRef]

16. Jaśkiewicz, B. Chemical composition of winter triticale grain depending on type of tillage in crop rotation. Eng. Rural Dev. Jelgava 2019, 319-323. [CrossRef]

17. Siekaniec, Ł.; Bereś, P.K.; Kaniuczak, Z. Chemical control of winter triticale leaves against diseases and leaf beetle larvae and its influence on economic indicators of cultivation in Podkarpacie voivodeship. Prog. Plant Prot. 2018, 58, 306-313. (In Polish) [CrossRef]

18. Labudda, M.; Machczyńska, J.; Woś, H.; Bednarek, P.T. Selected aspects of biological progress in the breeding of triticale(×Triticosecale WITTM. ex A. CAMUS)]. Post. Nauk Roln. 2011, 4, 3-10. (In Polish)

19. Jaśkiewicz, B. Specification of agrotechnics of semi-dwarf winter triticale. Stud. Rep. IUNG-PIB 2007, 9, 77-87. Available online: http://www.iung.pulawy.pl/images/wyd/pib/zesz9.pdf (accessed on 20 May 2020). (In Polish).

20. Sullivan, Z.M.; Honeyman, M.S.; Gibson, L.R.; Prusa, K.J. Effects of triticale-based diets on finishing pig performance and pork quality in deep-bedded hoop barns. Meat Sci. 2007, 76, 428-437. [CrossRef]

21. Brzozowska, I.; Brzozowski, J. Macronutrient contents in spring triticale grain depending on weed control method and level of nitrogen application. Fragm. Agron. 2016, 33, 15-22. (In Polish)

22. Wyszyński, Z.; Michalska-Klimczak, B.; Kamińska, S.; Leśniewska, J. Evaluation of winter triticale cultivation technology in production plantations in Łódź Voivodship. Ann. UMCS Sec. E Agric. 2017, LXXII, 113-123. [CrossRef]

23. Zhu, F. Triticale: Nutritional composition and food uses. Food Chem. 2018, 241, 468-479. [CrossRef]

24. Kronberga, A.; Legzdina, L.; Strazdina, V.; Vicupe, Z. Short communication comparison of selection results in organic and conventional environments for winter triticale. Proc. Latv. Acad. Sci. Sect. B 2013, 67, $268-271$. [CrossRef]

25. Achremowicz, B.; Ceglińska, A.; Gambuś, H.; Haber, T.; Obiedziński, M. Technological applicability of triticale grain. Postępy Techniki Przetwórstwa Spożywczego 2014, 1, 113-120. (In Polish)

26. Jaśkiewicz, B. The impact of production technology on yields of spring triticale under varied percentages of cereals to total cropped area. Fragm. Agron. 2017, 34, 7-17. (In Polish) 
27. Lenc, L.; Jończyk, K. Fusarium ear blight and the occurrence and harmfulness of fungi colonizing the grain of selected varieties of winter triticale (Triticale) grown in the organic system. Prog. Plant Prot. 2019, 59, 244-251. [CrossRef]

28. Dzienis, G. Winter rye-A species undervalued in Poland. A review. Agron. Sci. 2018, LXXIII, 19-28. [CrossRef]

29. Cierpiała, R.; Wesołowski, M. The production system in relation to spring barley grain yield and quality. Fragm. Agron. 2014, 31, 7-14. (In Polish)

30. Council Regulation (EC) No 834/2007 of 28th June 2007 on organic production and labelling of organic products and repealing Regulation (EEC) No 2092/91. Available online: http://eur-lex.europa.eu/legalcontent/EN/TXT/PDF/?uri=CELEX:32007R0834\&from=EN\T1\textgreater \{\} (accessed on 20 May 2020).

31. Le Campion, A.; Oury, F.-X.; Heumez, E.; Rolland, B. Conventional versus organic farming systems: Dissecting comparisons to improve cereal organic breeding strategies. Org. Agric. 2020, 10, 63-74. [CrossRef]

32. Kronberga, A. Formation of triticale crop ideotype for organic farming. In Cereal Science and Technology for Feeding Ten Billion People: Genomics Era and Beyond; Molina-Cano, J.L., Chistou, P., Graner, A., Hammer, K., Jouve, N., Keller, B., Lasa, J.M., Powell, W., Royo, C., Shewry, P., et al., Eds.; CIHEAM/IRTA: Zaragoza, Spain, 2008; pp. 391-393.

33. Kuś, J.; Mróz, A.; Jończyk, K. Intensity of fungal diseases of selected varieties of winter wheat cultivated in the organic crop production systems. J. Res. App. Agric. Eng. 2006, 51, 88-93. (In Polish)

34. Feledyn-Szewczyk, B. The evaluation of modern and old winter wheat varieties in the aspect of their competitiveness due to weeds in organic system. Pol. J. Agron. 2011, 6, 11-16. (In Polish)

35. Tendziagolska, E.; Kuc, P. The formation of weed infestation of winter rye under organic farming system depending on the method of sowing and the use of seed dressing and mineral fertilizer. Prog. Plant Prot. 2014, 54, 56-60. (In Polish) [CrossRef]

36. Finney, D.M.; Creamer, N.G. Weed Management on Organic Farms; The Organic Production Publication Series; Center for Environmental Farming Systems (CEFS), North Carolina Cooperative Extension Service: Raleigh, NC, USA, 2008; pp. 1-34.

37. Feledyn-Szewczyk, B. The weed infestation of spring wheat varieties cultivated in organic system. J. Res. App. Agric. Eng. 2011, 56, 71-76. (In Polish)

38. Urban, M.; Adamczewski, K.; Dobrzański, A. Ecological niche of weeds in spring cereals cultivars grown after winter oilseed rape. Prog. Plant Prot. 2013, 53, 105-109. (In Polish)

39. Feledyn-Szewczyk, B. Comparison of the competitiveness of modern and old winter wheat varieties in relation to weeds. J. Res. App. Agric. Eng. 2009, 54, 60-67. (In Polish)

40. Feledyn-Szewczyk, B.; Berbeć, A.K. Ranking of the competitive ability against weeds of 13 spring wheat varieties cultivated in organic system in different regions of Poland. J. Res. App. Agric. Eng. 2013, 58, 104-110.

41. Feledyn-Szewczyk, B.; I Kuś, J.; Jończyk, K.; Stalenga, J. The suitability of different winter and spring wheat varieties for cultivation in organic farming. In Organic Agriculture towards Sustainability; Pilipavicius, V., Ed.; InTech: Rijeka, Croatia, 2014; Volume 9, pp. 197-225. [CrossRef]

42. Feledyn-Szewczyk, B.; Berbeć, A.K.; Jończyk, K. The comparison of competitive ability against weeds of 10 varieties of rye cultivated in organic system. J. Res. App. Agric. Eng. 2014, 59, 35-40.

43. Feledyn-Szewczyk, B.; Jończyk, K. Assessment of the suitability of oat varieties (Avena sativa L.) for cultivation in organic system. J. Res. App. Agric. Eng. 2016, 61, 82-87.

44. Tottman, D.R.; Broad, H. The decimal code for the growth stages of cereals, with illustrations. Ann Appl Biol. 1987, 110, 441-454. [CrossRef]

45. Rutkowski, L. Key to identification of vascular plants in Lowland Poland; PWN: Warsaw, Poland, 2007; p. 822.

46. EPPO Standards. Guidelines for the Efficacy Evaluation of Plant Protection Products: PP 1/26, PP 1/28; EPPO: Paris, France, 1999; Volume 1, pp. 187-195.

47. Mahajan, G.; Hickey, L.; Chauhan, B.S. Response of barley genotypes to weed interference in Australia. Agronomy 2020, 10, 99. [CrossRef]

48. Szeleźniak, E.; Grabiński, J.; Nieróbca, P. Weed infestation of three grain species cultivated under cereal crop rotation and three technologies varying in production intensity. Acta Sci. Pol. Agric. 2007, 6, 83-90. (In Polish)

49. Starczewski, J.; Żołądek, J. Control of weed infestation by regulation of closeness of cultivated plants and herbicide application on the example of triticale. Zeszyty Problemowe Postępów Nauk Rolniczych 2003, 490, 235-240. (In Polish) 
50. Przystalski, M.; Osman, A.; Thiemt, E.M.; Rolland, B.; Ericson, L.; Østergård, H.; Levy, L.; Wolfe, M.; Büchse, A.; Piepho, H.-P.; et al. Comparing the performance of cereal varieties in organic and non-organic cropping systems in different European countries. Euphytica 2008, 163, 417-433. [CrossRef]

51. Wolfe, M.S.; Baresel, J.P.; Desclaux, D.; Goldringer, I.; Hoad, S.; Kovacs, G.; Löschenberger, F.; Miedaner, T.; Östergård, H.; Lammerts van Bueren, E.T. Developments in breeding cereals for organic agriculture. Euphytica 2008, 163, 323-346. [CrossRef]

52. Wróbel, E.; Jabłoński, H. Effect of fungal diseases control methods on winter triticale yield. Acta Sci. Pol. Agric. 2004, 3, 55-61. (In Polish)

53. Brzozowska, I.; Kurowska, A. Health status of spring triticale as dependent on weed control, nitrogen fertilization and protection against pathogens. Ann. UMCS Sec. E 2010, LXV, 38-47. (In Polish) [CrossRef]

54. Czajkowski, G.; Czembor, P. Pathogenicity of Blumeria graminis f. sp. tritici and Blumeria graminis f. sp. triticale the causal agents of wheat and triticale powdery mildew. Prog. Plant Prot. 2016, 56, 360-365. (In Polish) [CrossRef]

55. Kramek, A.; Kociuba, W. Characteristics of winter triticale genetic resources regarding field resistance to fungal diseases. Ann. UMCS, Sec. E 2014, LXIX, 112-119. (In Polish)

56. Korbas, M.; Mrówczyński, M. Methods of Integrated Protection of Winter and Spring Triticale for Producers; IOR-PIB: Poznań, Poland, 2012; p. 33. (In Polish)

57. Bujak, H.; Tratwal, A.; Walczak, F. Winter triticale yielding and value traits variability in Winna Góra. Ann. UMCS Sec. E 2012, LXVII, 1-11. (In Polish)

58. Jaśkiewicz, B.; Grabiński, J.; Ochmian, I. Productivity of winter triticale depending on type of tillage in crop rotation. Eng. Rural Dev. Jelgava 2018, 491-496. [CrossRef]

59. Jaśkiewicz, B.; Jasińska, M. The impact of tillage system on the yields of selected winter triticale cultivars. Fragm. Agron. 2018, 35, 61-70. (In Polish) [CrossRef]

60. Wenda-Piesik, A.; Wasilewski, P. Responses of spring wheat 'Monsun' and spring rye 'Bojko' to late autumn terms of sowing. Zeszyty Problemowe Postępów Nauk Rolniczych 2015, 580, 149-159. (In Polish)

61. Dekić, V.; Milovanović, M.; Popović, V.; Milivojević, J.; Staletić, M.; Jelić, M.; Perisić, V. Effects of fertilization on yield and grain quality in winter triticale. Rom. Agric. Res. 2014, 31, 1-9.

62. Koziara, W.; Panasiewicz, K.; Sulewska, H.; Sobieszczański, R. Effect of selected factors on yield and seed value of winter triticale var. Gniewko. Fragm. Agron. 2015, 32, 73-81. (In Polish) 